\title{
ОЦЕНКА СОСТОЯНИЯ ОТРАСЛЕВОЙ СТРУКТУРЫ НАЦИОНАЛЬНОЙ ЭКОНОМИКИ И ЭКОНОМИКИ РЕГИОНА ЧЕРЕЗ ПРИЗМУ НАЛОГООБЛОЖЕНИЯ ПРИБЫЛИ
}

\begin{abstract}
АНнотАция. В статье рассматривается сущность налогообложения и роль налога на прибыль как одного из основных фискальнозначимых и бюджетообразующих налогов. Обозначено значение прибыли как показателя финансовых результатов деятельности и положительных тенденций развития, а также сделан вывод о возможности такой оценки на основе налогооблагаемой прибыли и информации о суммах начисленного налога на прибыль. Описывается возможность использования анализа налоговых поступлений по налогу на прибыль в качестве инструмента оценки отраслевой структуры национальной экономики и экономики региона, складывающихся тенденций развития. На основе анализа поступления налога на прибыль организаций в целом по Российской Федерации и Иркутской области в частности сделаны выводы о сложившихся тенденциях в отраслевой структуре экономики. Выявлены отличительные особенности данных отраслевых тенденций и структурных соотношений в Иркутской области по сравнению со сложившимися тенденциями и структурными соотношениями по России.

кЛючЕВЫЕ СЛОВА. Налогообложение прибыли; прибыль как финансовый результат и объект налогообложения; отраслевая структура экономики; тенденции экономического развития.

ИНФОРМАЦИЯ О СТАТЬЕ. Дата поступления 15 марта 2016 г.; дата принятия к печати 6 апреля 2016 г.; дата онлайн-размещения 4 июля 2016 г.
\end{abstract}

N. V. Grokhotova

Baikal State University, Irkutsk, Russian Federation

\section{ASSESSING THE STATE OF SECTORAL STRUCTURE OF NATIONAL ECONOMY AND REGIONAL ECONOMY THROUGH THE PRISM OF PROFIT TAXATION}

ABSTRACT. The article considers the essence of taxation and the role of income tax as one of the main fiscally significant and budget-generating taxes. It identifies the profit value as an indicator of financial performance results and positive development trends, as well as makes a conclusion about possibility of such assessment on the basis of taxable profits and information on amounts of the profit tax charged. It describes the possibility of using an analysis of tax revenue from profit taxes as a tool for assessing the sectoral structure of the national economy and the regional economy, and emerging growth trends. On the basis of analysis of the profit tax receipts from organizations in the Russian Federation on the whole and Irkutsk Oblast in particular, the article makes conclusions about the current trends in the sectoral structure of the economy. It identifies distinctive features of data for sectorial trends and structural relationships in Irkutsk Oblast compared to the current trends and structural relationships in Russia.

KEYWORDS. Taxation of profit; profit as financial result and object of taxation; sectorial structure of economy; trends of economic development.

ARTICLE INFO. Received March 15, 2016; accepted April 6, 2016; available online July 4, 2016.

(C) H. В. Грохотова, 2016

\section{Baikal Research Journal}

электронный научный журнал Байкальского государственного университета 
В сложившейся финансовой практике анализ поступления налогов используется чаще всего в целях оценки налоговой нагрузки на экономику, эффективности налогового контроля и уровня собираемости налогов. Целью проводимого автором исследования выступило изучение возможности применения анализа налогов в качестве инструмента оценки отраслевой структуры экономики и призмы, с использованием которой можно рассмотреть складывающиеся отраслевые пропорции и наметившиеся в экономике тенденции.

Большая часть экономистов ученых сходятся во мнении о том, что налогообложение представляет собой объективный экономический процесс обобществления части созданных в производстве и приращенных в обращении финансовых ресурсов в пользу всего общества [1-4]. Оно берет свое начало из производства стоимости и распределения ее денежной формы. Как утверждает Т. Г. Потапова, что одной из важнейших экономических категорий, имеющих общественное назначение, являются налоги, реализующие конкретные экономические функции [5, с. 203]. Как указывается в авторской монографии, критическое осмысление подходов к дефиниции налога, налогообложения, его принципов и функций позволяет системно использовать их наиболее рациональные моменты [7, с. 106].

Налоги как качественно и количественно обоснованный поток преимущественно денежных ресурсов движутся из сферы «бизнес» в сферу «бюджет», затрагивая взаимопротивоположные интересы субъектов - участников налоговых отношений [6, с. 21]. Налог на прибыль является основным прямым налогом с организаций и входит в пятерку фискальнозначимых, бюджетообразующих налогов. В соответствии с действующим законодательством организации, получившие прибыль, должны 20 \% от суммы своего положительного результата уплатить в бюджет в виде налога. Доля таких организаций в структуре зарегистрированных налогоплательщиков налога на прибыль в целом по России за 2011-2014 гг. находилась в пределах 40 \% , а по Иркутской области - в пределах 45-48 \% (менее половины от их общего количества) ${ }^{1}$.

Вопросы обеспечения доходности деятельности хозяйствующего субъекта во все времена были актуальны, поэтому ученые-экономисты уделяют особое внимание такой категории, как прибыль, подразумевая под ней все формы дохода: процент, предпринимательский доход, рента и др. [8-10].

Современная экономическая наука рассматривает прибыль как доход, получаемый в результате использования факторов производства: труда, земли и капитала. Общим для всех авторов концепций и точек зрения на экономическую категорию «прибыль» является ее признание в качестве обобщающего показателя финансовых результатов деятельности организации [8-11]. Как указывает О. В. Гафарова, в реальной действительности прибыль - конечная цель и движущий мотив товарного производства рыночной экономики. Это главный стимул и основной показатель эффективности любого предприятия. Высокие прибыли заставляют капиталы мигрировать из одной отрасли в другую [11, с. 32].

Прибыль является одним из финансовых результатов деятельности организации и создает определенные гарантии для дальнейшего существования и развития фирмы, а также свидетельствует о его успешной деятельности [12, с. 17]. В соответствии с п. 1 ст. 38 Налогового кодекса РФ прибыль является объектом налогообложения, так как относится к стоимостным характеристикам, с которыми законодательство о налогах и сборах связывает возникновение у налогоплательщика обязанности по уплате налога.

${ }^{1}$ Отчет о налоговой базе и структуре начислений по налогу на прибыль организаций. № 5-П. URL : http://www.nalog.ru.

\section{Baikal Research Journal}

электронный научный журнал Байкальского государственного университета 
По мнению И. А. Майбурова, Ю. Б. Иванова, налог как экономическая категория выполняет определенные функции в системе категорий: функцию распределения дохода или другого ресурса между государством и хозяйствующим субъектом, функцию наполнения бюджетной системы денежными ресурсами и др. [13, с. 77].

Информация о величине прибыли как о показателе финансовых результатов деятельности формируется в соответствии с бухгалтерским законодательством и аналогичными стандартами и отражается в бухгалтерской (финансовой) отчетности. Величина прибыли как налоговой базы определяется на основе данных налогового учета, осуществляемого организацией в соответствии с правилами, установленными ст. 25 Налогового кодекса РФ.

Несмотря на существующие различия в правилах определения бухгалтерской и налогооблагаемой прибыли, можно предположить, что посредством анализа объемов поступления налога на прибыль можно оценивать прибыльность деятельности организаций в различных отраслях народного хозяйства, делать выводы о тенденциях развития тех или иных отраслей.

Национальную экономику любого государства можно рассматривать как сложную хозяйственную, социальную, организационную, научно-технологическую систему. Все социально-экономические процессы, протекающие в этой системе, охватывают материальные, трудовые, финансовые, природные и прочие ресурсы, вовлекаемые в хозяйственный оборот, и в совокупном взаимодействии представляют собой единый процесс воспроизводства. Каждая отрасль народного хозяйства представляет собой совокупность хозяйствующих субъектов, различающихся масштабами деятельности, формами собственности, организационной и производственной структурой и другими характеристиками.

Используя данные налоговых органов о суммах начисленных налогов, рассмотрим динамику поступления налога на прибыль по отраслям народного хозяйства в целом по Российской Федерации за 2011-2014 гг. ${ }^{2}$ (рис. 1). За анализируемый период величина поступлений налога на прибыль в консолидированный бюджет РФ выросла всего на $1,13 \%$ и в 2014 г. составила 2294,14 млрд р. В 2013 г. отмечалось снижение поступлений налога практически по всем отраслям, что объясняется негативным влиянием общероссийского экономического спада. Поступление налога на прибыль в консолидированный бюджет РФ в 2014 г. превысили объемы налога за 2013 г. почти на $12 \%$. Однако и даже такой существенный рост поступлений налога только позволил достичь показателей 2011 г. и несущественно их превысить.

В разрезе по отраслям выйти в 2014 г. на уровень, превышающий объемы уплаченного налога на прибыль в 2011 г., удалось только организациям трех отраслей. Налог на прибыль, уплачиваемый организациями оптовой и розничной торговли в 2014 г. вырос по сравнению с 2011 г. на 57 \% и составил 537,96 млрд р. Прирост налога на прибыль по организациям, занятым в сфере финансовой деятельности, составил почти $26 \%$, а по организациям, занятым в строительном производстве $15 \%$. Объемы налога на прибыль, уплачиваемые организациями, осуществляющими деятельность в сфере добычи полезных ископаемых и обрабатывающего производства, остались примерно в тех же пределах. А вот объемы налоговых платежей по налогу на прибыль по организациям таких отраслей, как производство и передача электроэнергии, транспорт и связь, операции с недвижимым имуществом снизились более чем на $30 \%$.

${ }^{2}$ Отчет о начислении и поступлении налогов и сборов по основным видам экономической деятельности, форма. № 1-HOM. URL : http://www.nalog.ru.

\section{Baikal Research Journal}

электронный научный журнал Байкальского государственного университета 


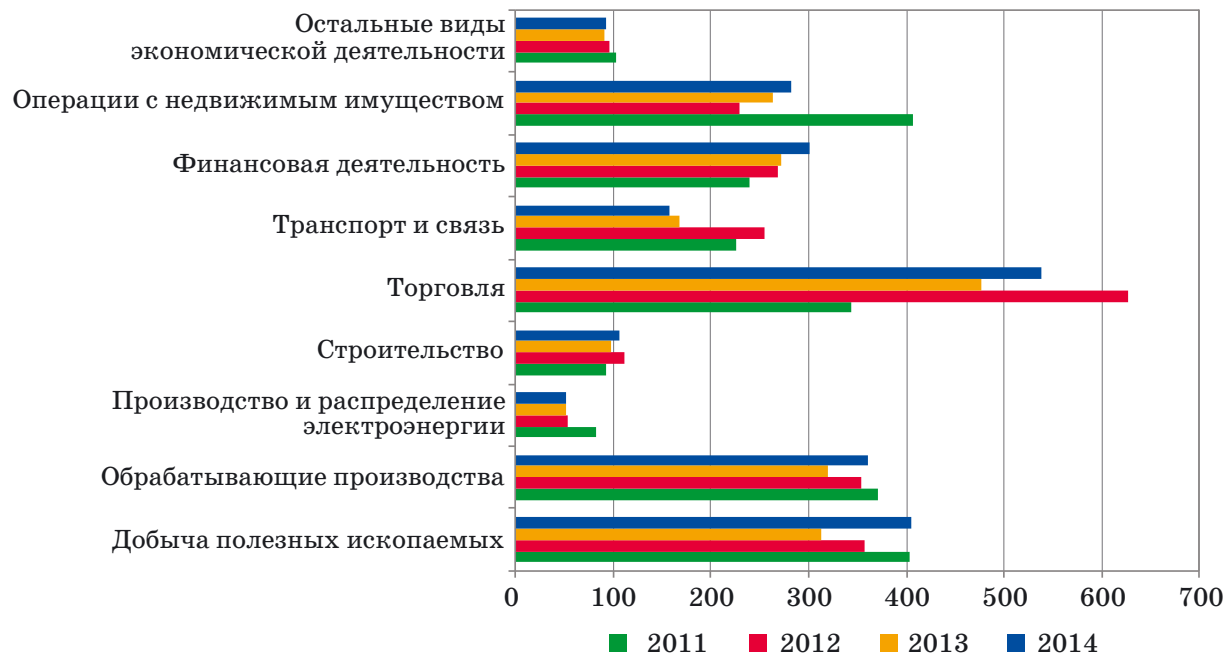

Рис. 1. Динамика поступлений налога на прибыль организаций по Российской Федерации за 2011-2014 гг., млрдр.

Выявленную динамику можно рассматривать как сигнал о негативных тенденциях, складывающихся в деятельности организаций данных отраслей, и особенно, в сфере транспорта и связи. Для России, как государства с площадью 17,13 млн км² ${ }^{2}$ занимающей 31,8 \% евроазиатского континента, вопросы рентабельности и стабильности функционирования организаций транспортной сферы являются немаловажными.

Следует отметить, что общий объем поступления налога на прибыль по Иркутской области имеет тенденцию, аналогичную общероссийской, но в разрезе по отраслям народного хозяйства мы видим несколько иную картину (рис. 2). В 2014 г. выйти на уровень, превышающий объемы налога, уплаченного в 2011 г., удалось организациям четырех отраслей. Лидирующую позицию заняли организации добывающей отрасли. Сумма налога, уплаченного ими в 2014 г. по сравнению с 2011 г., выросла на $40 \%$ и составила 15,3 млрд р.

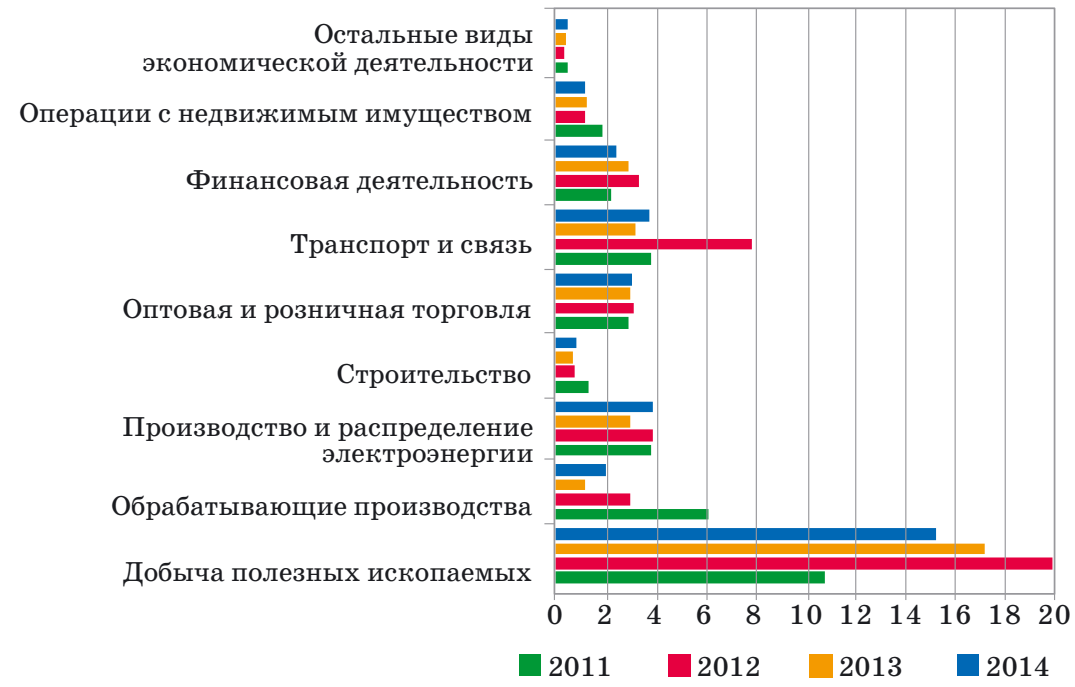

Рис. 2. Диналика поступлений налога на прибыль организаций по Иркутской области за 2011-2014 г2., ллрдр.

\section{Baikal Research Journal}


Суммы налога на прибыль, уплаченные организациями, осуществляющими деятельность в финансовой сфере, выросли на 8,5 \% ; в сфере оптовой и розничной торговли - на 3,5 \%, а в сфере производства и распределения электроэнергии - всего на 1,3\% . Резкое снижение объемов уплачиваемого налога на прибыль наблюдается по организациям, осуществляющим деятельность в сфере обрабатывающего производства. Сумма налога, поступающего в бюджетную систему от организаций данной отрасли, снизилась более чем на $60 \%$.

Остановимся на рассмотрении роли отраслей народного хозяйства в формировании налоговых доходов по налогу на прибыль в целом по Российской Федерации. Для этой цели проведем анализ структурных соотношений за 2011 и 2014 гг. (рис. 3-4).

Остальные виды экономической деятельности

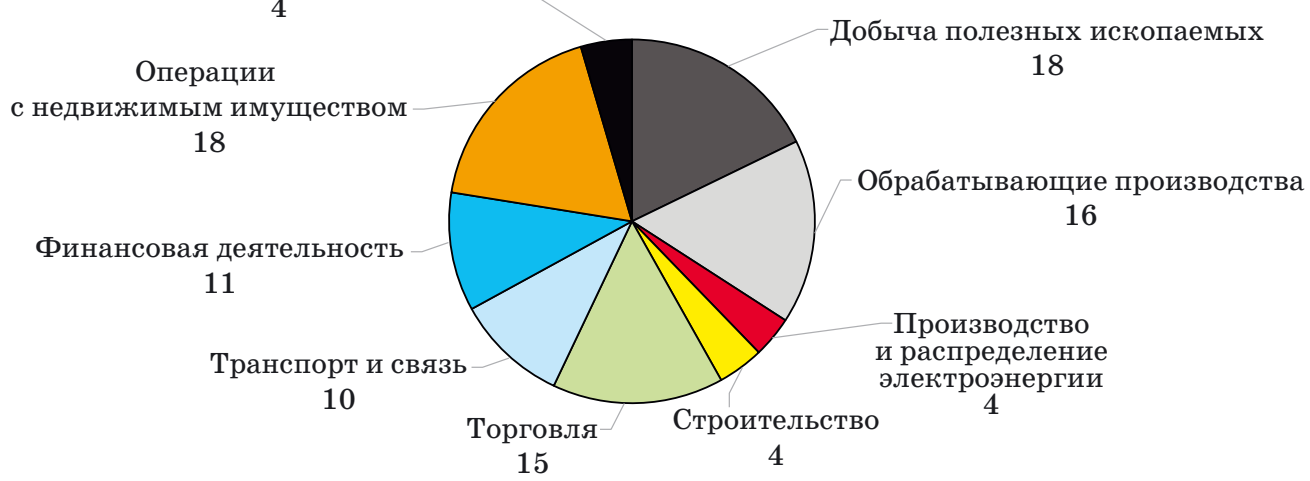

Рис. 3. Структура поступлений налога на прибыль в консолидированный бюджет Российской Федерации в 2011 г., \%

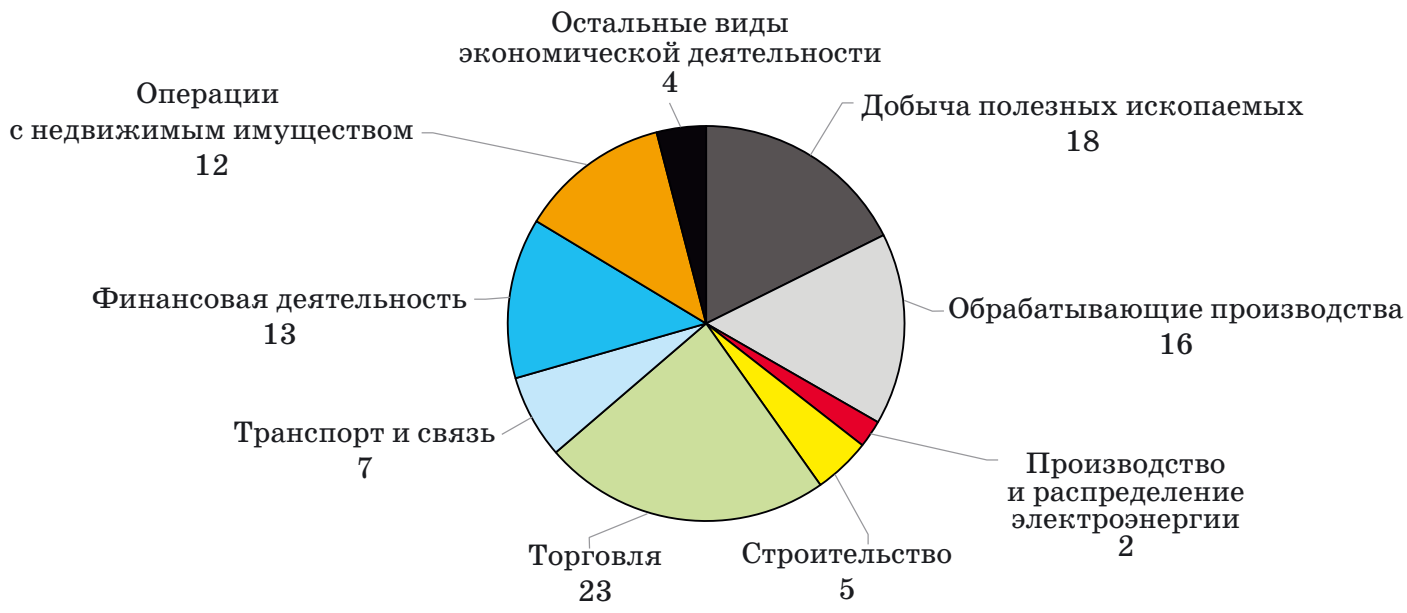

Рис. 4. Структура поступлений налога на прибыль в консолидированный бюджет Российской Федерации в 2014 г., \%

В структуре поступлений налога на прибыль фискальную роль в 2011 г. играли организации таких отраслей, как добыча полезных ископаемых (18 \% ), операции с недвижимым имуществом (18\%), обрабатывающее производство (16 \%) и торговля $(15 \%)$.

\section{Baikal Research Journal}


В 2014 г. структурные соотношения существенно изменились. Явную лидирующую позицию занимают организации торговой сферы, на их долю приходится $23 \%$ от общей суммы налога на прибыль. При этом следует иметь в виду, что значительная часть хозяйствующих субъектов, осуществляющих торговую деятельность, относятся к субъектам малого бизнеса, и, как правило, применяя специальные налоговые режимы, плательщиками налога на прибыль не являются.

Фискальное значение организаций сферы добычи полезных ископаемых и обрабатывающего производства в 2014 г. по сравнению с 2011 г. не изменилось. Доля организаций транспорта и связи в формировании налоговых поступлений по налогу на прибыль снизилась с 10 до 7\% .

Исходя из того, что хозяйствующие субъекты таких сфер деятельности, как операции с недвижимым имуществом, финансовая деятельность, транспорт и связь, торговля, не относятся к сфере материального производства, то доля последней в формировании налоговых поступлений налога на прибыль в бюджетную систему Российской Федерации в 2011 г. составляла $46 \%$. В 2014 г. на долю материального производства приходится 45 \% всех налоговых поступлений, что составляет менее половины.

Таким образом, сложившиеся в национальной экономике России отраслевые пропорции, оцениваемые через призму налогообложения прибыли, нельзя признать оптимальными.

В структуре поступлений налога на прибыль в 2011 г. по Иркутской области на долю организаций, занятых в добывающей отрасли, приходится $33 \%$ от всех поступлений. Значимую фискальную роль также играют предприятия обрабатывающего производства (18\%), организации, занятые в сфере производства и распределения электроэнергии, транспорта и связи (по 11 \% соответственно). Доля налога на прибыль, уплачиваемая торговыми организациями Иркутской области, составляет в общем объеме всего 9 \% (рис. 5).

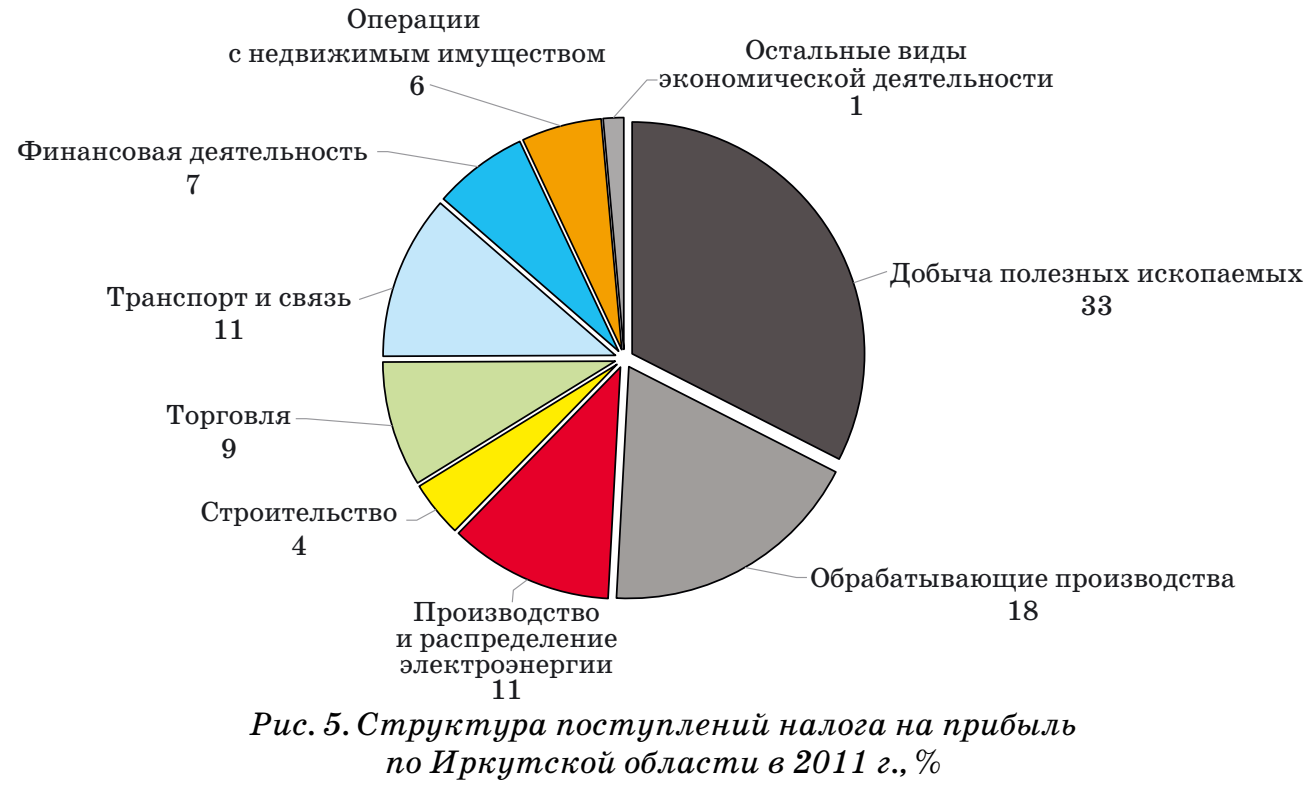

В 2014 г. в структуре поступления налога на прибыль по Иркутской области также произошли существенные изменения, но они отличаются от тенденции, сложившейся в целом по России (рис. 6).

\section{Baikal Research Journal}




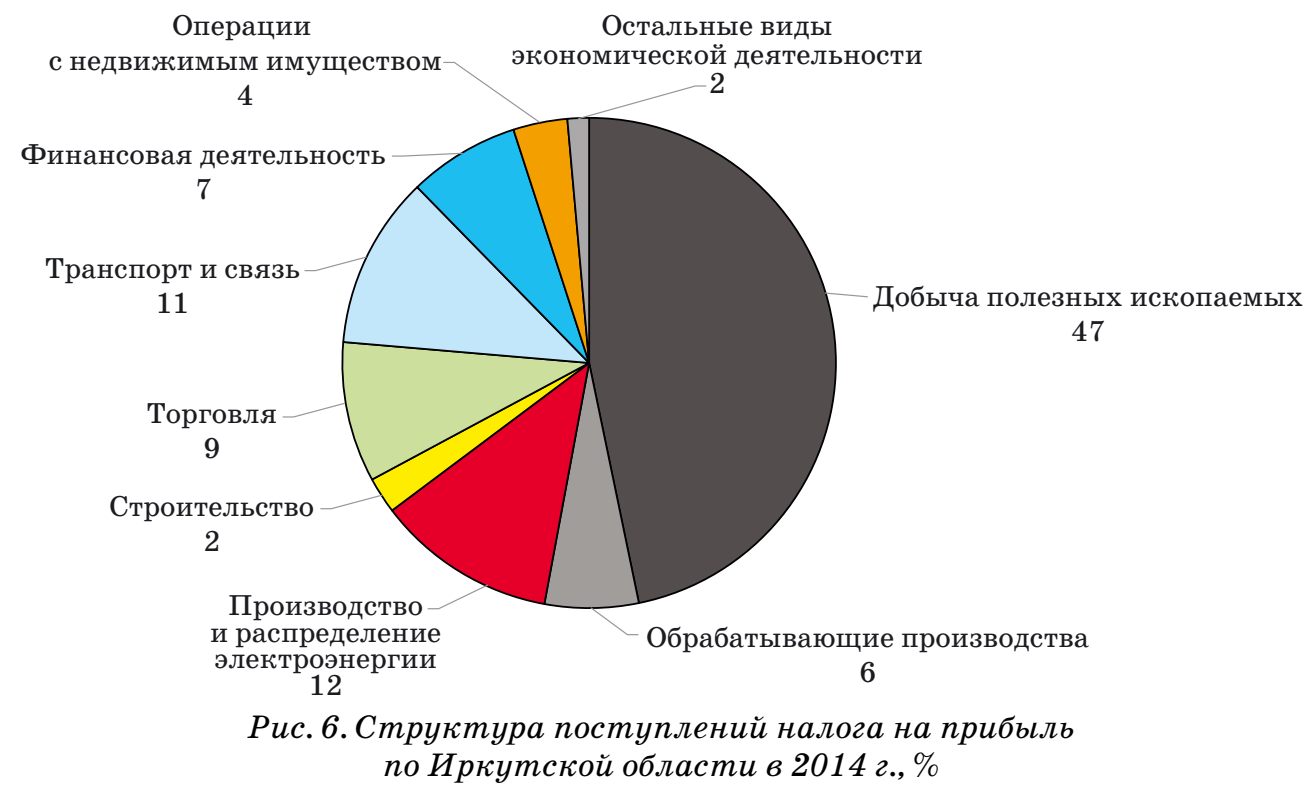

Доля налога на прибыль, уплачиваемого организациями добывающей отрасли, значительно выросла с 33 до 47 \% и составила почти половину от всей суммы поступлений налога. Свои фискальные позиции сохранили за собой организации таких сфер деятельности, как производство и передача электроэнергии, транспорт и связь, торговля. Существенное снижение фискальной роли в формировании налоговых доходов по налогу на прибыль произошло в отношении организаций, осуществляющих свою деятельность в сфере перерабатывающего производства. Их доля снизилась в три раза (с 18 до 6 \%), что говорит о сложившейся негативной тенденции, возможных существенных финансовых проблемах хозяйствующих субъектов данной сферы, требующих внимания со стороны региональных властей.

Доля материального производства в формировании налоговых доходов по налогу на прибыль по Иркутской области существенно выше, чем в целом по Российской Федерации, и составляет в 2011 и в 2014 гг. 67 и 69 \% соответственно. В сравнении с общероссийскими пропорциями данное соотношение является наиболее оптимальным, но существенная доля добывающей отрасли свидетельствует об однобокости экономического развития региона и необходимости внесения корректив в проводимую государственную и региональную политику регулирования экономического развития.

Как показывают данные отчетности Федеральной налоговой службы России, что от всех организаций, состоящих на налоговом учете, порядка одна треть их них не предоставляют в налоговые органы декларации по налогу на прибыль ${ }^{3}$. Данный факт, по мнению автора, существенно не искажает сложившуюся по результатам анализа картину. Большая часть данных предприятий относится к организациям «однодневкам» или к организациям, так и не приступившим к осуществлению своей заявленной деятельности.

Таким образом, проведенный анализ налоговых поступлений по налогу на прибыль позволяет сделать определенные выводы о сложившейся отраслевой структуре экономики в целом по России и по ее отдельно взятому субъекту. Через призму налогообложения прибыли возможно выявить нерациональные структурные соотношения и наметившиеся негативные тенденции экономического развития, расши-

\footnotetext{
${ }^{3}$ Отчет о налоговой базе ... № 5-П.
}

\section{Baikal Research Journal}


рить возможности налогового анализа как косвенного инструмента экономической оценки не только финансовых результатов, но и объемов деятельности, и имущественного состояния, используя для этой цели данные о суммах других уплачиваемых налогоплательщиками налогов.

\section{Список использованной литературы}

1. Мартазанова А. К. Социально-экономическая сущность налогов и налогообложения / А. К. Мартазанова / Экономические и гуманитарные науки. — 2013. — № 5 (256). — С. 54-63.

2. Семерова О. С. Экономическая сущность налогообложения, функции, классификация и система налогов и сборов в России / О. С. Семерова // Актуальные вопросы налогообложения, налогового администрирования и экономической безопасности : материалы регион. науч.-практ. конф., посвящ. 25-летию ФНС России, 29 окт. 2015 г. / отв. ред. Л. В. Севрюкова. - Курск : Юго-Зап. гос. ун-т, 2015. - С. 60-65.

3. Лапшина 3. В. Сущность налогов и способы их классификации / 3. В. Лапшина, К. С. Прахт // Экономика и социум. - 2015. - № 2-3 (15). - С. 25-27.

4. Шайхутдинова Д. Р. Справедливость как основной принцип налогообложения [Электронный ресурс] / Д. Р. Шайхутдинова // Управление экономическими системами. - 2012. № 6 (42). - Режим доступа : http://uecs.ru/uecs42-422012/item/1405-2012-06-15-06-06-31.

5. Потапова Т. Г. Функции налога как экономической категории / Т. Г. Потапова // Проблемы экономики России и Монголии : сб. науч. тр. - Иркутск : Изд-во БГУЭП, 2013. С. 201-204.

6. Грохотова Н. В. Налоговый менеджмент и его влияние на формирование прибыли организации : дис. ... канд. экон. наук : 08.00.10 / Н. В. Грохотова. - Иркутск, 2005. - 220 с.

7. Фискальный федерализм. Проблемы и перспективы развития : моногр. для магистрантов, обучающихся по программам направления «Финансы и кредит» / под ред. И. А. Майбурова, Ю. Б. Иванова. - М. : Юнити-Дана, 2015. - 415 с.

8. Мануйленко В. В. Экономическая сущность, виды и функции прибыли хозяйствующего субъекта: современный аспект / В. В. Мануйленко, Т. А. Садовская // Финансовая аналитика: проблемы и решения. - 2012. - № 33. - С. 2-11.

9. Соколова Е. К. Экономическая сущность прибыли и рентабельности, факторы их определяющие / Е. К. Соколова / Экономика, финансы и менеджмент: тенденции и перспективы развития : материалы по итогам Междунар. науч.-практ. конф., 15-16 нояб. 2014 г. - Волгоград : Инновац. центр развития образования и науки, 2014. - Вып. 2. - С. 102-104.

10. Цугуй А. Ф. Экономическая сущность прибыли / А. Ф. Цугуй / Н Наука и образование в XXI веке : материалы Междунар. науч.-практ. конф., 30 янв. 2015 г. : в 5 ч. - М. : АР-Консалт, 2015. - Ч. 2. - C. 114-115.

11. Гафарова О. В. Экономическая природа прибыли как основа налогообложения предприятий [Электронный ресурс] / О. В. Гафарова. - Режим доступа : http://elibrary.ru/item. asp?id=16529562.

12. Уянаева К. А. Прибыль как экономическая категория [Электронный ресурс] / K. А. Уянаева. - Режим доступа : http://elibrary.ru/item.asp?id=21047218.

13. Налоговые реформы. Теория и практика : моногр. для магистрантов, обучающихся по специальностям «Финансы и кредит», «Бухгалтерский учет, анализ и аудит» / под ред. И. А. Майбурова, Ю. Б. Иванова. - М. : Юнити-Дана, 2010. - 463 с.

\section{References}

1. Martazanova A. K. Socio-economic summary of taxes and taxation. Ekonomicheskie $i$ gumanitarnye nauki $=$ The Humanities and Social Sciences, 2013, no. 5 (256), pp. 54-63. (In Russian).

2. Semerova O. S. Economic essence of taxation, functions, classification and system of taxes and levies in Russia. In Sevryukova L. V. Aktual'nye voprosy nalogooblozheniya, nalogovogo administrirovaniya i ekonomicheskoi bezopasnosti. Materialy regional'noi nauchno-prakticheskoi konferentsii, posvyashchennoi 25-letiyu FNS Rossii, $29 \mathrm{okm} .2015$ g. [Topical issues of taxation, tax administration and economic security. Materials of Science and Practice Conference devoted to 25-th anniversary of Russia's Federal Tax Service, October 29, 2015]. Kursk, Southwest State University Publ., 2015, pp. 60-65. (In Russian).

\section{Baikal Research Journal}


3. Lapshina Z. V., Prakht K. S. Essence of taxes and ways of their classification. Ekonomika $i$ sotsium = Economy and Socium, 2015, no. 2-3 (15), pp. 25-27. (In Russian).

4. Shaikhutdinova D. R. Justice as the basic principle of taxation. Upravlenie ekonomich eskimi sistemami = Management of Economic Systems, 2012, no. 6 (42). Available at: http:// uecs.ru/uecs42-422012/item/1405-2012-06-15-06-06-31. (In Russian).

5. Potapova T. G. Tax functions as an economic category. Problemy ekonomiki Rossii i Mongolii [Economic problems of Russia and Mongolia]. Irkutsk, Baikal State University of Economics and Law Publ., 2013, pp. 201-204. (In Russian).

6. Grokhotova N. V. Nalogovyi menedzhment i ego vliyanie na formirovanie pribyli organizat sii. Kand. Diss. [Tax management and its impact on developing the organization's profit. Cand. Diss.]. Irkutsk, 2005. 220 p.

7. Maiburov I. A., Ivanov Yu. B. (eds). Fiskal'nyi federalizm. Problemy i perspektivy razvi tiya [Fiscal Federalism. Problems and prospects of development]. Moscow, Yuniti-Dana Publ., 2015. $415 \mathrm{p}$.

8. Manuilenko V. V., Sadovskaya T. A. Economic essence, types and functions of profit of the economic entity: modern aspect. Finansovaya analitika: problemy i resheniya = Financial Analytics: Science and Experience, 2012, no. 33, pp. 2-11. (In Russian).

9. Sokolova E. K. Economic nature of profit and profitability: factors that determine them. Ekonomika, finansy i menedzhment: tendentsii i perspektivy razvitiya. Materialy Mezhdunarodnoi nauchno-prakticheskoi konferentsii, 15-16 noyabrya $2014 \mathrm{~g}$. [Economy, finance and management: trends and development prospects. Materials of International Research Conference, November 15-16, 2014]. Volgograd, Innovative Centre for Development of Education and Science Publ., 2014, iss. 2, pp. 102-104. (In Russian).

10. Tsugui A. F. Economic nature of profit. Nauka i obrazovanie v XXI veke. Materialy Mezhdunarodnoi nauchno-prakticheskoi konferentsii, 30 yanvarya $2015 \mathrm{~g}$. [Science and education in XXI century. Materials of International Research Conference, January 30, 2015]. Moscow, AR-Konsalt Publ., 2015, pp. 114-115.

11. Gafarova O. V. Ekonomicheskaya priroda pribyli kak osnova nalogooblozheniya predpriyatii [Economic nature of profit as the basis of enterprise taxation]. Available at: http://elibrary. $\mathrm{ru} / \mathrm{item}$.asp?id=16529562.

12. Uyanayeva K. A. Pribyl kak ekonomicheskaya kategoriya [Profit as an economic category]. Available at: http://elibrary.ru/item.asp?id=21047218.

13. Maiburov I. A., Ivanov Yu. B. (eds). Nalogovye reformy. Teoriya i praktika [Tax reforms. Theory and practice]. Moscow, Yuniti-Dana Publ., 2012. 463 p.

\section{Информация об авторе}

Грохотова Наталья Викторовна - кандидат экономических наук, заведующий кафедрой налогов и бухгалтерского учета, филиал Байкальского государственного университета в г. Братске, 665719, г. Братск, ул. Карла Маркса, 14, e-mail: nvg1412@yandex.ru.

\section{Author}

Natalya V. Grokhotova - PhD in Economics, Head of Chair of Taxes and Acounting, Baikal State University, 14 K. Marx St., 665719, Bratsk, Russian Federation, e-mail: nvg1412@yandex.ru.

\section{Библиографическое описание статьи}

Грохотова Н. В. Оценка состояния отраслевой структуры национальной экономики и экономики региона через призму налогообложения прибыли / Н. В. Грохотова / Baikal Research Journal. — 2016. — T. 7, № 4. — DOI : 10.17150/2411-6262.2016.7(4).10.

\section{Reference to article}

Grokhotova N. V. Assessing the state of sectoral structure of national economy and regional economy through the prism of profit taxation. Baikal Research Journal, 2016, vol. 7, no. 4. DOI : 10.17150/2411-6262.2016.7(4).10. (In Russian).

\section{Baikal Research Journal}

